\title{
R353Q polymorphism in the factor VII gene and cardiovascular risk in Heterozygous Familial Hypercholesterolemia: a case-control study
}

\author{
Juan Criado-García', Francisco Fuentes ${ }^{1}$, Cristina Cruz-Teno ${ }^{1}$, Antonio García-Rios ${ }^{1}$, Anabel Jiménez-Morales', \\ Javier Delgado-Lista ${ }^{1}$, Pedro Mata ${ }^{2}$, Rodrigo Alonso² ${ }^{2}$ José López-Miranda ${ }^{1}$ and Francisco Pérez-Jiménez ${ }^{1 *}$, for \\ Spanish Group for the Study of Familiar Hypercholesterolemia ${ }^{1}$
}

\begin{abstract}
Background: Heterozygous Familial Hypercholesterolemia (FH) is a genetic disorder characterized by a high risk of cardiovascular disease. Certain polymorphisms of the factor VII gene have been associated with the development of coronary artery disease and there is a known association between factor VII levels and polymorphic variants in this gene. To date, no study has evaluated the association between factor VII and coronary artery disease in patients with $\mathrm{FH}$.

Results: This case-control study comprised 720 patients (546 with FH and 174 controls). We determined the prevalence and allele frequencies of the R353Q polymorphism of factor VII, the plasma levels of factor VII antigen (FVII Ag) and whether they could be predictive factors for cardiovascular risk. 75\% (410) of the patients with $\mathrm{FH}$ were RR, 23\% (127) RQ and 1.6\% (9) QQ; in the control group 75.3\% (131) were RR, 21.3\% (37) RQ and 3.4\% (6) QQ $(p=0.32)$. No statistically significant associations were observed in the distribution of genotypes and allele frequencies between case $(\mathrm{FH})$ and control groups. Nor did we find differences when we evaluated the relationship between the $\mathrm{R} 353 \mathrm{Q}$ polymorphism and cardiovascular risk (including coronary disease, ischemic stroke and peripheral arterial disease), either in the univariate analysis or after adjustment for sex, age, arterial hypertension, body mass index, xanthomas, diabetes, smoking, HDLC and LDLC and lipid-lowering treatment. The FVII Ag concentrations behaved in a similar fashion, with no differences for the interaction between controls and those with FH (RR vs. RQ/QQ; $p=0.96$ ). In the subgroup of patients with $\mathrm{FH}$ no association was found among cardiovascular disease, genotype and FVII Ag levels (RR vs. RQ/QQ; $p=0.97$ ).
\end{abstract}

Conclusions: Our study did not find a direct relationship between cardiovascular risk in patients with Heterozygous Familial Hypercholesterolemia, the R353Q polymorphism of factor VII and FVII Ag levels.

Keywords: Familial Hypercholesterolemia Factor VII, R353Q polymorphism

\section{Bakground}

Heterozygous Familial Hypercholesterolemia (FH) is an autosomal codominant disease caused by defects in the low-density lipoprotein receptor (LDLR) gene [1]. It is a genetic disorder characterized by elevated levels of plasma low-density lipoproteins cholesterol (LDLc)

\footnotetext{
* Correspondence: fperezjimenez@uco.es

'Lipids and Atherosclerosis Unit, Department of Medicine, IMIBIC/Hospital Universitario Reina Sofía/Universidad de Córdoba, Córdoba, Spain and CIBER Fisiopatología Obesidad y Nutrición (CIBEROBN), Instituto de Salud Carlos III, Madrid, Spain

Full list of author information is available at the end of the article
}

ranging from 300 to $400 \mathrm{mg} / \mathrm{dl}$, corneal arcus, tendon xanthomas and a high prevalence of early-onset coronary disease. It is extremely heterogeneous, with an incidence of one in 500 persons $(0.2 \%)$ [2,3]. The study of the mechanisms that encourage the development of cardiovascular disease (CVD) is of great interest, given the variability both of the clinical picture and in the therapeutic response that characterizes this disease. Moreover, not all diagnosed patients present clinical symptoms, so a better understanding of the factors that lead to some patients developing early-onset CVD while

\section{Biomed Central}


others do not, would be very useful as a means of evaluating the risk and adopting preventive measures.

In patients at high CVD risk, such as patients with $\mathrm{FH}$, there appears to be a chronic activation of the mechanisms of coagulation and hemostasis, which leads to what is regarded as a permanent prothrombotic condition $[4,5]$. Thrombosis is the basis of the most acute manifestations of coronary artery disease. The atheromatous plaque rupture, with the consequent exposure of tissue factor to blood and its subsequent union with factor VII (FVII), initiates the coagulation cascade [6]. One of the components of hemostasis that has aroused interest for its potential role in the development of coronary disease and stroke is FVII. Some studies have associated high levels of plasma FVII with an elevated risk of coronary artery disease [7-10], although these findings have not been confirmed by other studies leading to highly variable results $[11,12]$. The R353Q polymorphism of the FVII gene has been among those most closely associated with variations in plasma levels of FVII [13-16]. This is a simple nucleotide polymorphism (SNP), characterized by the substitution of a guanine base by an adenine, which involves the substitution of arginine (R) by glutamine $(\mathrm{Q})$ in codon 353 of this protein [8]. Lower levels of FVII have been detected in carriers of the $\mathrm{Q}$ allele than in individuals who are homozygous for the more common $\mathrm{R}$ allele $[17,18]$. Carriers of the $\mathrm{Q}$ allele may therefore be protected against acute thrombotic events, as has been demonstrated by a number of case-control studies in which the $\mathrm{Q}$ allele was associated with a reduced risk of acute myocardial infarct [19-24]; however, this association was weaker [25] or was not detected in another studies [26-28].

The principal objectives of this study were therefore to analyze the prevalence and allele frequency of the R353Q polymorphism and the plasma FVII levels in FH patients with or without CVD and in family members who were unaffected by FH (controls), and to determine whether the presence of this polymorphism could be a predictor of CVD risk in these patients.

\section{Material and methods}

\section{Study design and study population}

This was a case-control study of a sample population selected from a Spanish FH Longitudinal Cohort Study, supported by the "Fundación Española de Hipercolesterolemia Familiar" http://www.colesterolfamiliar.com. One person per familiy (index case) was also included. The clinical diagnosis of $\mathrm{FH}$ was made in accordance with the diagnostic criteria homogenized by the MEDPED international cooperative program, which is coordinated by the World Health Organization (WHO) [29]. All patients with FH included in the study were heterozygous carriers for known functional mutations in the
LDLR gene. This FH genetic diagnosis was carried out also in control patients, assuring the no-FH diagnosis. A written informed consent was obtained from all participants before their inclusion in the cohort and the protocol was approved by the ethic committee of the CEIC Fundación Jiménez Díaz (Madrid). STREGA criteria were used in the reporting of our study [30,31].

We determined the polymorphism in 720 patients. Among them there were 546 persons affected by $\mathrm{FH}$ (cases) and 174 family members unaffected by FH (controls). Clinical data concerning sex, age, history of arterial hypertension (HT), smoking, diabetes mellitus (DM), body mass index (BMI), xanthomas, total cholesterol level, triglycerides, LDLc, high-density lipoproteins cholesterol (HDLc), treatment for hyperlipemia and CVD were collected.

\section{Cardiovascular events}

The evaluation and definition of CVD events was based on the WHO MONICA project [32]. CVD was classified as "early onset" when it occurred at an age of less than 55 years in men and 65 in women. CVD events were evaluated via analysis of the CVD history of the patient himself and those of his first-degree (parents, siblings and children) and second-degree (grandparents, aunts and uncles, cousins and nieces and nephews by blood) family who had a documented clinical history of a) ischemic cardiopulmonary (myocardial infarct, angina pectoris, surgery or any other coronary revascularization procedure), b) cerebrovascular disease or c) peripheral vascular disease.

\section{Sampling procedures}

On enrollment in the study, blood samples were obtained by venous puncture from fasting patients. Samples were sent to a central laboratory for the extraction of genomic DNA from the leukocyte fraction of fresh blood, using the Puregen ${ }^{\circledR}$ (DNA isolation kit, Gentra Systems, MN, U.S.A). The genomic DNA was used for the determination of the R353Q mutation of the FVII coagulation gene.

\section{Determination of FVII polymorphism}

FVII polymorphism was determined according to Lindman et al. [33], by real-time polymerase chain reaction (RT-PCR) (Stratagene Mx3005P Cultek) of a DNA region of exon 8 of the FVII coagulation gene. We used $150 \mathrm{ng}$ of genomic DNA, $3 \mathrm{mM}$ of $\mathrm{MgCl} 2,200 \mu \mathrm{M}$ of each nucleotide, 1 IU of Hot Start polymerase and reaction buffer to $1 \mathrm{X}$ (Dominion-MBL).

The primers were mixed with the probe (GATGCCCGTCAGGTACCACGTGCCC (C/T) GGTA GTGGGTGGCATGTGGGCCTCC) to $1 \mathrm{X}$ in a final volume of $10 \mu \mathrm{l}$ (Taqman ${ }^{\circledR}$-Applied Biosystems). The 
DNA was denatured at $95^{\circ} \mathrm{C}$ for $5 \mathrm{~min}$, followed by 40 cycles of denaturation at $95^{\circ} \mathrm{C}$ for $30 \mathrm{~s}$, a phase of primer-polymerase union $\left(60^{\circ} \mathrm{C}\right.$ for $\left.1 \mathrm{~min}\right)$ and extension $\left(72^{\circ} \mathrm{C}\right.$ for $\left.30 \mathrm{~s}\right)$. The population genotypes were subsequently analyzed using the curves supplied by the RTPRC equipment. In the R353Q assay, a guanine base is replaced by an adenine, which requires the substitution of arginine ( $\mathrm{R})$ by glutamine (Q) in codon 353 of this protein.

Standard good laboratory practices were undertaken to ensure the accuracy of genotype data, including the inclusion of dummy duplicates.

\section{Determination of plasma FVII Ag concentrations}

FVII Ag levels were determined using an Elisa Kit (AssayMax Human Factor VII ELISA Kit ${ }^{\circledR}$, Assaypro) with a minimum detectable dose $<6 \mathrm{ng} / \mathrm{ml}$ and an intra and inter-assay coefficients of variation of $5.0 \%$ and $7.1 \%$ respectively.

\section{Quantification of plasma lipid levels}

Plasma lipid levels $(\mathrm{mg} / \mathrm{dl})$ were determined by spectrophotometry (enzymetric colorimetry) in a Modular Analytics ISE-4-DDPPEEPP autoanalyzer (F. Hoffmann-La Roche, Basle, Switzerland); an oxidation-peroxidation method was employed to assay total cholesterol, HDLc and triglycerides; LDLc was estimated by Friedewald's formula (LDLc = total cholesterol - triglycerides $/ 5$ HDLc).

\section{Statistical analysis}

The SPSS statistical package (version 17.0 for Windows) was utilized for all statistical analyses, which comprised:

- descriptive analysis of absolute and relative frequencies with 95\% confidence intervals (CI) and means and standard deviations of the quantitative variables.

- comparison of qualitative variables using chisquared contingency tables; in the case of $2 \times 2$ tables, the chi-squared table alone was used, while if any expected frequency was $<5$, Fisher's exact test was employed.

- comparisons of the mean values of the quantitative variables by means of Student's t-test for two independent samples or single-factor analysis of variance for more than two independent samples.

In all the statistical tests, values of $\mathrm{p}<0.05$ were treated as significant and the hypothesized contrasts were bilateral.

In order to evaluate the association of the FVII genotype with CVD, we calculated the odds ratio (crude OR) and its $95 \%$ CI by univariate logistical regressions. In order to control for sex, age, HT, BMI, xanthomas, DM, LDLc, HDLc, smoking and lipid-lowering therapy, we employed a multivariate logistics model (adjusted OR).

\section{Results}

\section{Baseline characteristics}

The general characteristics of the patients are shown in Table 1. No significant differences were found in the following variables: sex, BMI, HT, DM or triglyceride levels between the $\mathrm{FH}$ and control groups. However there were differences in age, total cholesterol, LDLc and HDLc levels, xanthomas (102 of $546 \mathrm{HF}$ patients developed them, $18.9 \%$ ), in those patients under lipidlowering treatment (more than $83 \%$ of the $\mathrm{FH}$ ), in the number of CVD events as well as in global CVD and in the mean age of the first event.

\section{Cardiovascular disease}

In $14.7 \%$ of the patients with FH a CVD event occurred; 75 patients developed coronary artery disease, 4 cerebrovascular disease and 12 peripheral arterial disease. In the distribution by vascular territories, $71 \%$ of FH with CVD had affectation of a single territory while in $9 \%$, two or more territories were affected, with a statistically significant difference in the distribution of the CVD events compared with the control group ( $p<0.001)$. We must emphasize the low frequency of cerebrovascular disease in both the control (1.7\%) and the FH group $(0.7 \%)$, with no significant difference between them $(p=0.37)$. The frequency of peripheral vascular disease (predominantly in the lower extremities) was $2.1 \%$ in $\mathrm{FH}$ patients and $0.5 \%$ in the controls $(\mathrm{p}=0.21)$.

\section{The R353Q polymorphism}

In the analysis of the R353Q genotypes distribution (Table 2), we found that $75.1 \%$ of the patients with $\mathrm{FH}$ were RR, 21.3\% were RQ and 3.4\% QQ, without any evidence of differences between the control and $\mathrm{FH}$ groups $(\mathrm{p}=0.32)$. Similar results were obtained when we analyzed this genotypes distribution comparing RR vs RQ/ QQ ( $p=0.96)$. In the allele frequencies $(R$ or $Q$ allele presence), we found no statistically significant differences between case $(\mathrm{FH})$ and control groups (0.86 and 0.87 , IC 95\% $0.82,0.89$ and $0.85,0.89$ respectively for the R allele; 0.14 and 0.13 , IC 95\% $0.11,0.18$ and 0.11 , 0.15 respectively for the $\mathrm{Q}$ allele). The allele frequencies in both were adjusted to the Hardy-Weinberg equilibrium ( $\mathrm{p}=0.97$ and $\mathrm{p}=28$, respectively).

\section{Polymorphism and cardiovascular risk}

In order to identify possible relationships between the different genotypes and higher or lower prevalence of CVD in FH patients (Table 3), we performed an univariate analysis. With respect to global CVD we found no 
Table 1 Basic characteristics of patients and controls

\begin{tabular}{|c|c|c|c|}
\hline & Controls $N=174$ & Familial hypercholesterolemia $N=546$ & Value of $P$ \\
\hline Age (years) & $39.7 \pm 17.5$ & $43.5 \pm 16.3$ & 0.009 \\
\hline Women (\%) & 55.7 & 47.3 & 0.62 \\
\hline $\mathrm{BMI}$ & 25.7 & 26.6 & 0.20 \\
\hline $\mathrm{HT}(\%)$ & 10.3 & 12.7 & 0.41 \\
\hline DM (\%) & 2.3 & 2.4 & 1.000 \\
\hline Total cholesterol (mg/dl) & $239.6 \pm 70.3$ & $270.3 \pm 70.4$ & $<0.001$ \\
\hline Triglycerides (mg/dl) & $102.2 \pm 61.1$ & $109.1 \pm 62.5$ & 0.22 \\
\hline LDLc (mg/dl) & $168.4 \pm 68.4$ & $201.3 \pm 67.1$ & $<0.001$ \\
\hline $\mathrm{HDLC}(\mathrm{mg} / \mathrm{dl})$ & $50.2 \pm 13.4$ & $46.1 \pm 13.2$ & $<0.001$ \\
\hline Xanthomas & 0.0 & $102(18.6 \%)$ & $<0.001$ \\
\hline Smoking (\%) & 46.8 & 49.4 & 0.55 \\
\hline$\underline{\text { Lipid-lowering treatment }}$ & $66(37.9 \%)$ & $458(83.9 \%)$ & $<0.001$ \\
\hline CV disease & $8(4.6 \%)$ & $80(14.7 \%)$ & $<0.001$ \\
\hline First CV event (years) & $57.1 \pm 13.3$ & $46.7 \pm 11.1$ & 0.01 \\
\hline Coronary artery disease & $6(3.4 \%)$ & $75(13.7 \%)$ & $<0.001$ \\
\hline Cerebrovascular disease & $3(1.7 \%)$ & $4(0.7 \%)$ & 0.37 \\
\hline Peripheral arterial disease & $1(0.5 \%)$ & $12(2.1 \%)$ & 0.21 \\
\hline \multicolumn{4}{|l|}{ CVD distribution: } \\
\hline -single territory & $6(3.5 \%)$ & $71(13 \%)$ & $<0.001$ \\
\hline -two or more territories & $2(1.2 \%)$ & $9(1.6 \%)$ & \\
\hline
\end{tabular}

Values expressed as means \pm standard deviation. BMI: body mass index, calculated by dividing weight by height squared. HT: arterial hypertension. DM: diabetes mellitus. CV: cardiovascular. LDLc: low-density lipoproteins cholesterol. HDLc: high-density lipoproteins cholesterol.

statistical differences between carriers of the RR and RQ genotypes, just as in those subjects who were homozygous for the non-dominant gene (RR genotype). The separately analysis of coronary artery disease and peripheral vascular disease led to same results; this analysis could not be applied to cerebrovascular disease because of its low incidence (four subjects). Multivariate logistic regression analysis, adjusted for sex, age, HT, BMI, xanthomas, DM, HDLc, LDLc, smoking habit and treatment for hyperlipemia found no association between the genotypes of the FVII R353Q mutation and CVD.

\section{FVII Ag levels}

Plasma FVII Ag levels $(\mathrm{ng} / \mathrm{mL}$ ) were determined in a subgroup of 320 patients, 160 controls (including 8 with CVD) and $160 \mathrm{FH}$ patients (80 with CVD). The genotypes distribution (RR vs RQ/QQ) between both groups was similar $(p>0.05)$. Analysis of variance for two factors (FH and genotype) adjusted for sex, age, DM, smoking, HT and CVD was applied and no differences were found in FVII Ag levels for the interaction between both factors $(\mathrm{p}=0.96)$ (Table 4$)$. We also studied the FVII Ag concentration in patients with FH $(n=160)$

Table 2 FVII genotype polymorphisms of FH and control patients

\begin{tabular}{lccc}
\hline \multicolumn{1}{c}{ Controls $\boldsymbol{N}=\mathbf{1 7 4}$} & Familiar hypercholesterolemia $\boldsymbol{N}=\mathbf{5 4 6}$ & Total $\boldsymbol{N}=\mathbf{7 2 0}$ & Value of $\mathbf{P}^{*}$ \\
\hline $\begin{array}{l}\text { Genotype } \\
\text { R353Q FVII }\end{array}$ & $131(75.3 \%)$ & & \\
\hline$R R$ & $37(21.3 \%)$ & $127(23.3 \%)$ & $541(75.1 \%)$ \\
\hline$R Q$ & $6(3.4 \%)$ & $9(1.6 \%)$ & $164(22.8 \%)$ \\
\hline$Q Q$ & & & $15(2.1 \%)$ \\
\hline$R R$ & $131(75.3 \%)$ & $410(75.1 \%)$ & $541(75.1 \%)$ \\
\hline$R Q / Q Q$ & $43(24.7 \%)$ & $136(24.9 \%)$ & $179(24.9 \%)$ \\
\hline Allele frequency & $0.86(0.82-0.89)$ & & 0.96 \\
$R$ & $0.14(0.11-0.18)$ & $0.87(0.85-0.89)$ & \\
$Q$ & $0.13(0.11-0.15)$ & \\
\hline
\end{tabular}

*P values expressed by $\chi 2$ (Pearson). FVII: Factor VII. 
Table 3 Multivariate analysis of FH patients

\begin{tabular}{|c|c|c|c|c|c|c|c|}
\hline \multicolumn{8}{|c|}{ CVD Patients (\%) } \\
\hline & $\begin{array}{l}\text { Patients } \\
(\mathrm{n}=546)\end{array}$ & $\begin{array}{c}\text { No } \\
(n=466)\end{array}$ & $\begin{array}{c}\text { Yes } \\
(n=80)\end{array}$ & OR (Cl 95\%)* & $P$ & Adjusted $\mathrm{OR}^{* *}(\mathrm{Cl} 95 \%)$ & $P$ \\
\hline \multicolumn{8}{|l|}{ FVII } \\
\hline $\mathrm{RR}$ & 410 & $350(75.1)$ & $60(75.0)$ & 1.00 (Reference) & & 1.00 (Reference) & \\
\hline $\mathrm{RQ}$ & 127 & $110(23.6)$ & $17(21.3)$ & $0.89(0.50-1.59)$ & 0.70 & $0.76(0.36-1.58)$ & 0.46 \\
\hline QQ & 9 & $6(1.3)$ & $3(3.7)$ & $2.88(0.70-11.84)$ & 0.14 & $3.53(0.66-18.92)$ & 0.14 \\
\hline \multirow[t]{3}{*}{$\mathrm{RQ} / \mathrm{QQ}$} & 136 & $116(24.9)$ & $20(25.0)$ & $0.99(0.58-1.72)$ & 0.98 & $0.89(0.45-1.78)$ & 0.75 \\
\hline & \multicolumn{7}{|c|}{ CAD Patients (\%) } \\
\hline & $\begin{array}{l}\text { Patients } \\
(\mathrm{n}=546)\end{array}$ & $\begin{array}{c}\text { No } \\
(n=471)\end{array}$ & $\begin{array}{c}\text { Yes } \\
(n=75)\end{array}$ & OR (Cl 95\%)* & $P$ & Adjusted $\mathrm{OR}^{* *}(\mathrm{Cl}$ 95\%) & $P$ \\
\hline \multicolumn{8}{|l|}{ FVII } \\
\hline RR & 410 & $354(75.1)$ & $56(74.7)$ & 1.00 (Reference) & & 1.00 (Reference) & \\
\hline $\mathrm{RQ}$ & 127 & $111(23.5)$ & $16(21.3)$ & $0.90(0.50-1.63)$ & 0.73 & $0.90(0.43-1.87)$ & 0.77 \\
\hline QQ & 9 & $6(1.4)$ & $3(4.0)$ & $3.12(0.76-12.86)$ & 0.11 & $3.33(0.64-17.24)$ & 0.15 \\
\hline \multirow[t]{3}{*}{$\mathrm{RQ} / \mathrm{QQ}$} & 136 & $117(24.9)$ & $19(24.3)$ & $1.02(0.58-1.78)$ & 0.96 & $1.05(0.52-2.08)$ & 0.90 \\
\hline & \multicolumn{7}{|c|}{ PAD Patients (\%) } \\
\hline & $\begin{array}{l}\text { Patients } \\
(\mathrm{n}=546)\end{array}$ & $\begin{array}{c}\text { No } \\
(n=534)\end{array}$ & $\begin{array}{c}\text { Yes } \\
(n=12)\end{array}$ & OR (Cl 95\%)* & $P$ & Adjusted $\mathrm{OR}^{* *}(\mathrm{Cl}$ 95\%) & $P$ \\
\hline \multicolumn{8}{|l|}{ FVII } \\
\hline RR & 410 & $401(75.1)$ & $9(75.0)$ & 1.00 (Reference) & & 1.00 (Reference) & \\
\hline $\mathrm{RQ}$ & 127 & $125(23.4)$ & $2(13.7)$ & $0.71(0.15-3.34)$ & 0.67 & $0.78(0.15-3.84)$ & 0.76 \\
\hline QQ & 9 & $8(1.5)$ & $1(8.3)$ & $5.56(0.63-49.33)$ & 0.12 & $5.77(0.26-125.96)$ & 0.26 \\
\hline RQ/QQ & 136 & $132(24.9)$ & $3(24.0)$ & $1.00(0.27-3.77)$ & 0.99 & $1.03(0.26-4.17)$ & 0.96 \\
\hline
\end{tabular}

*Crude OR obtained by univariate logistic regression analysis. **Multivariate logistic regression adjusted for sex, age, body mass index, xanthomas, arterial hypertension, smoking, diabetes mellitus, LDLc, HDLc and lipid-lowering treatment. FVII: Factor VII. FH: Heterozygous Familial Hypercholesterolemia. CVD: cardiovascular disease. CAD: coronary artery disease. PAD: peripheral artery disease.

depending on the presence or not of CVD; in the analysis of variance for CVD and genotype adjusted for age, sex, DM, smoking and HT no differences were found for the interaction between them $(\mathrm{p}=0.97)$ (Table 5).

\section{Discussion}

In our study, the R353Q polymorphism of the FVII gene, its allele frequency and the FVII Ag levels neither predict nor are directly related to the prevalence of CVD in FH patients.

$\mathrm{FH}$ is the monogenetic disease with the highest prevalence in human beings and it is associated with a high risk of early and serious CVD. The global prevalence of
CVD in this study was $14.7 \%$, with a mean age of $45.5 \pm$ 16.3 years, while it is estimated that in general spanish population the prevalence in the same age range is $2.6 \%$ [34]. The prevalence of $\mathrm{FH}$ is highly variable in western populations, being as high as $39 \%$ in some series [35]. These variations have been attributed to a number of factors, such as the different diagnostic criteria (genetic or clinical) used in the FH studies, differences in the methodologies employed and the possible direct influence of environmental factors, such as diet. In fact, it has been demonstrated that consumption of a Mediterranean diet rich in olive oil reduces the incidence of CVD in the general population [34], even leading to a

Table 4 FVII Ag levels in controls and FH patients

\begin{tabular}{cccc}
\hline & & Controls $(\mathbf{n}=\mathbf{1 6 0})$ & Familiar hypercholesterolemia $(\mathbf{n}=\mathbf{1 6 0})$ \\
\hline $\begin{array}{c}\text { Genotype } \\
\text { R353Q FVII }\end{array}$ & $\begin{array}{c}\text { FVII levels } \\
(\mathbf{n g} / \mathbf{m L})\end{array}$ & \\
\hline RR $(n=120)$ & Mean & $374.6 \pm 239.6$ & $292.8 \pm 157.6$ \\
\cline { 2 - 4 } & Adjusted mean & $372.9 \pm 204.7$ & $288.6 \pm 211.2$ \\
\hline RQ/QQ $(n=40)$ & Mean & $387.5 \pm 248.2$ & $293.9 \pm 200.2$ \\
\cline { 2 - 4 } & Adjusted mean & $376.7 \pm 198.1$ & 130.8 \\
\hline
\end{tabular}

Values expressed as means \pm standard deviation. Analysis of variance for two factors (FH and genotype) adjusted for age, sex, diabetes, smoking, arterial hypertension and cardiovascular disease. No differences were found for the interaction between both factors (0.96). FVII: Factor VII. 
Table 5 FVII Ag levels in FH patients and CVD

\begin{tabular}{cccc}
\hline & & \multicolumn{2}{c}{ CVD } \\
\cline { 2 - 4 } & & $\begin{array}{c}\text { No } \\
(\mathbf{n}=\mathbf{8 0})\end{array}$ & $\begin{array}{c}\text { Yes } \\
(\mathbf{n}=\mathbf{8 0})\end{array}$ \\
\hline $\begin{array}{c}\text { Genotype } \\
\text { R353Q FVII }\end{array}$ & $\begin{array}{c}\text { FVII levels } \\
(\mathbf{n g} / \mathbf{m L})\end{array}$ & & \\
\hline RR $(n=60)$ & Mean & $307.1 \pm 175.4$ & $278.6 \pm 137.5$ \\
\cline { 2 - 4 } & Adjusted mean & $260.9 \pm 240.0$ & $311.7 \pm 167.7$ \\
\hline RQ/QQ $(n=20)$ & Mean & $219.7 \pm 111.2$ & $311.4 \pm 135.5$ \\
\cline { 2 - 4 } & Adjusted mean & $213.3 \pm 168.1$ & $359.9 \pm 152.3$ \\
\hline
\end{tabular}

Values expressed as means \pm standard deviation. Analysis of variance for two factors (CVD and genotype) adjusted for age, sex, diabetes mellitus, smoking and arterial hypertension. No differences were found for the interaction between both factors (0.97). CVD: cardiovascular disease. FVII: Factor VII.

reduction in the level of activated FVII [37], which would also have a direct influence on subjects with $\mathrm{FH}$. The phenotypic expression of $\mathrm{FH}$ in terms of onset and severity of atherosclerotic vascular disease varies considerably. A paucity of consistent data exist on factors that contribute to these phenotypic differences. Several studies have analyzed the influence of traditional CVD risk factors and the functional variety of LDLR mutation on this phenotypic variability [38,39]. However, they can only partially explain the observed differences. Therefore other still unknown factors, such as genetic conditions, could play an important role in the development of CVD in these patients. This is sustained by the fact that clustering of CVD occurs in FH kindred. The genetic variability of this population sample would be determined by the presence or absence of certain polymorphisms as potential predictor of CVD risk. Also a number of studies have demonstrated that FH patients with xanthomas have a higher risk of CVD compared to those without them $[40,41]$. A recent meta-analysis has demonstrated this fact concluding that the presence of tendon xanthomas is associated with a 3 times higher risk of CVD among FH patients, suggesting that xanthomas and CVD may share a common etiology [42]. Our population had a $14.7 \%$ of global CVD prevalence, very low if we compare it with another FH cohort as Simon Broome [43], whose global prevalence was much higher (60\%). In Simon Broome cohort, $48 \%$ of FH patients presented with tendon xanthomas; this fact could partially justify the highest prevalence of CVD when we compared it with our study where only $18.6 \%$ developed them. This low prevalence of CVD could be explained by the low presence of tendon xanthomas in our population. On the other hand we should also considered that Simon Broome cohort used clinical criteria for $\mathrm{FH}$ diagnosis; in our cohort genetic diagnosis of $\mathrm{FH}$ was carried out in all cases.

Among those potentially interesting genes of such phenotypic variability is FVII gene. Several of its polymorphisms have been associated with differences in the risk of suffering CVD events when they have been analyzed in groups of severe atherosclerosis patients $[18,19,23,24]$, basically due to variations in their levels and plasma activity, which may encourage a state of hypercoagulability $[13,16]$. Our study analyzed the different types of the R353Q polymorphism of FVII gene in a sample of $\mathrm{FH}$ patients, comparing their potential association with CVD (coronary, cerebrovascular and peripheral artery disease). Some studies have suggested that global CVD risk appears to be independent of the R353Q polymorphism of FVII [44-46]; however, a metaanalysis has demonstrated that bearers of the Q allele are at lesser risk [47]. Furthermore, a lower rate of myocardial infarcts has been observed in such populations $[23,24]$. Several studies have described a reduction in circulating FVII levels in patients who are heterozygous (RQ) or homozygous (QQ) for the non-dominant gene thus associating these levels with the presence of the $\mathrm{Q}$ allele $[13,14]$. One study by Girelli et al. has even suggested a possible protective effect of this allele, as a means of explaining why patients with severe coronary arteriosclerosis do not evolve acute myocardial infarct [18]. In the face of these results, the data from our study, in which the frequency distribution of the various FVII alleles is identical to that of the general population $[33,48]$, do not shown any differences in terms of CVD frequency between the subjects who are homozygous for the various alleles when patients, with or without $\mathrm{FH}$, are compared. Although FH patients are at high risk of CVD, they do not present differences in the frequency of CVD events as a function of being carriers, or not, of either allele. The fact that these patients present elevated levels of total cholesterol and LDLc, and lower levels of HDLc (these being factors that are independent of the development of early-onset cardiovascular phenomena), may have influenced our results, without such findings having been observed in association with allele Q. On the other hand, there was no causal relationship between the carriers of the $\mathrm{R}$ allele, which determines the most frequent genotype in the population, and development of CVD.

Respecting plasma FVII Ag levels our data do not shown differences in controls and FH patients and no relation could be established with the genotype and also with its allelic distribution (RR vs. RQ/QQ). These results contrast with some studies that found lower FVII levels in carriers of $\mathrm{Q}$ allele [13] and moreover no protective effect could be attributed to $Q$ allele in our population [14]. In the subgroup of patients affected of $\mathrm{FH}$, the comparison between those with or without CVD showed no change in the adjusted mean levels of FVII depending on genotype. All these circumstances would support the absence of association between the 
R353Q polymorphism and CVD risk in our FH patients, according to all those studies where global CVD risk appears to be independent of the R353Q polymorphism of FVII [44-46].

We must also consider, as one of the possible reasons that could justify this lack of relation between the polymorphism and CVD, the low number of cardiovascular events developed in our FH patients (14.7\%), probably because of their mean age, just $43.5 \pm 16.3$ with an age in the first CV event of $46.7 \pm 11.1$ years. Jansen et al [49], who investigated the contribution of polymorphisms in multiple candidate genes to CVD risk, found a $33.1 \%$ of CVD frequency in their FH cohort, where the mean age of onset of CVD was 48.2 years, although they analyzed patients with age at last visit of $56.4 \pm 11.4$ years.

\section{Conclusions}

We are unaware of any study that has associated FVII with CVD risk in FH patients and our study is thus a pioneer in this respect. It has been well demonstrated that there are variations in the concentration and activity of FVII as a function of the genotype involved, with these being lower in carriers of the $\mathrm{Q}$ allele. As our data have shown, therefore, the R353Q polymorphism of FVII gene does not predict cardiovascular risk in the sample of FH patients in the Spanish Cohort.

\section{Disclosures}

None of the authors had any conflict of interest.

\section{Funding Sources}

This work was supported by research grants from the Centro Nacional de Investigaciones Cardiovasculares (CNIC-08-2008), National Health Institute; CIBER (CBO/6/03), Instituto de Salud Carlos III; CICYT (SAF 01/2466-C05 04 to F P-J, SAF 01/0366 to J L-M, AGL 2004-07907 to J L-M, AGL 2006-01979 to JL-M), the Spanish Ministry of Health (FIS 01/0449, FIS PI041619 to CM); Fundación Cultural "Hospital Reina Sofía-Cajasur; Consejería de Salud, Servicio Andaluz de Salud (00/ 212, 00/39, 01/239, 01/243, 02/64, 02/65, 02/78, 03/73, 03/75, 04/237, 04/191, 04/238, 05/396); Consejería de Educación, Plan Andaluz de Investigación, Universidad de Córdoba; Centro Excelencia Investigadora Aceite de Oliva y Salud (CEAS); NIH grants HL54776 and DK07503; Fundación Española de Hipercolesterolemia Familiar.

\section{List of Abbreviations}

FH: Heterozygous Familial Hypercholesterolemia; LDLR: low-density lipoprotein receptor; CVD: cardiovascular disease; FVII: factor VIl; FVII Ag: factor VII antigen; HDLc: high-density lipoproteins cholesterol; LDLc: lowdensity lipoproteins cholesterol; DM: diabetes mellitus; BMI: body mass index; HT: arterial hypertension.

\section{Acknowledgements}

This study was performed using data obtained from the Heterozygous Familial Hypercholesterolemia Cohort Study and from the medical centers currently active in that project:

Fundación Jiménez Díaz de Madrid (Pedro Mata - Rodrigo Alonso Karlezi) Hospital Universitario Reina Sofía de Córdoba (Francisco Fuentes Jiménez) Hospital Universitario Virgen del Rocío, Sevilla (José Villar Ortiz - Ovidio Muñiz Grijalvo)

Hospital Ramón y Cajal, Madrid (Clotilde Vázquez Martínez -Francisco Arrieta) Hospital de Mérida, Badajoz (Pedro Sáenz Aranzubia)

Hospital de Elche, Alicante (Mar Piedecausa-Selfa - Ana Maestre Peiró) Hospital San Pedro de Alcántara, Cáceres (Juan Francisco Sánchez MuñozTorrero)

Hospital Clínico, Barcelona (Daniel Zambón Rados)

Hospital Donostia, Donostia (Fátima Almagro Múgica)

Hospital Central, Asturias (Pilar Gómez Enterría - Ceferino Martínez Faedo)

Hospital Ciudad Real, Ciudad Real (Jesús Galiana Gómez del Pulgar)

Hospital Nuestra Señora de la Candelaria, Tenerife (Francisca Pereyra

-Mercedes Muros)

Hospital Comarcal Vega Baja, Orihuela, Alicante (José María Cepeda Rodrigo), and with the direct support of CIBER (CB06/03), Instituto de Salud Carlos III and Centro Nacional de Investigaciones Cardiovasculares Carlos III (CNIC 082008; Plan Nacional de Investigación, Ministerio de Ciencia e Innovación). Special acknowledgments to Elisa Muñoz (IMIBIC/Reina Sofía University Hospital) in the statistical analysis and interpretation.

The CIBEROBN is an initiative of the Instituto de Salud Carlos III, Madrid, Spain.

\section{Author details}

${ }^{1}$ Lipids and Atherosclerosis Unit, Department of Medicine, IMIBIC/Hospital Universitario Reina Sofía/Universidad de Córdoba, Córdoba, Spain and CIBER Fisiopatología Obesidad y Nutrición (CIBEROBN), Instituto de Salud Carlos III, Madrid, Spain. 'Lipid Clinic. Internal Medicine. IIS- Fundación Jiménez Díaz, Madrid, Spain.

\section{Authors' contributions}

JCG: Development of study design, determination of FVII polymorphism and FVII Ag concentrations, statistical analysis and interpretation, draft manuscript. FF: Development of study design, collection data and analysis and interpretation. CCT: Determination of FVII polymorphism and FVII Ag concentrations. AGR: Collection data. AJM: Development of study design, statistical analysis. JDL: Statistical analysis. PM: Collection and data interpretation. RA: Collection and data interpretation. JLM: Development of study design, statistical analysis and interpretation. FPJ: Development of study design, statistical analysis and interpretation. All authors have read and approved the final manuscript.

Received: 27 February 2011 Accepted: 9 April 2011 Published: 9 April 2011

\section{References}

1. Goldstein JL: Familial hypercholesterolemia. In The Metabolic and Molecular Bases of Inherited Disease. Edited by: Scriver CR, Beaudet AL, Sly WS, Valle E. New York: McGraw-Hill; 2001:2863-913.

2. Goldstein JL, Schrott HJ, Hazzard WR, Bierman EL, Motulsky AG: Hyperlipidemia in coronary heart disease. II. Genetic analysis of lipid levels in 176 families and delineation of a new inherited disorder, combined hyperlipidemia. J Clin Invest 1973, 52:1544-68.

3. Soutar AK, Naoumova RP: Mechanisms of disease: genetic causes of familial hypercholesterolemia. Nat Clin Pract Cardiovasc Med 2007, 4:214-25, Review.

4. Pérez-Jiménez F, Lista JD, Pérez-Martínez P, López-Segura F, Fuentes F, Cortés B, Lozano A, López-Miranda J: Olive and haemostasis: a review on its healthy effects. Public Health Nutr 2006, 9(8A):1083-8, Review.

5. Mutanen M, Freese R: Fats, lipids and blood coagulation. Curr Opin Lipidol 2001, 12:25-29.

6. Fuster V, Badimon L, Badimon JJ, Chesebro JH: Mechanisms of disease-the pathogenesis of coronary artery disease and the acute syndromes. $N$ Engl J Med 1992, 326:242-50.

7. Meade TW, Mellows S, Brozovic M, Miller GJ, Chakrabarti WR, North WR, Haineer AP, Stirling Y, Imeson JD, Thomson SG: Haemostatic function and 
ischaemic heart disease: principal results of the Northwick Park heart study. Lancet 1986, 2:533-7.

8. Heinrich J, Balleisen L, Schulte H, Assmann G, vandeLoo J: Fibrinogen and factor VII in the prediction of coronary risk. Results from de PROCAAM study in healthy men. Arterioscler Thromb 1994, 14:54-9.

9. Campo G, Valgimigli M, Ferraresi P, Malagutti P, Baroni M, Arcozzi C, Gemmati D, Percoco G, Parrinello G, Ferrari R, Bernardi F: Tissue factor and coagulation factor VII levels during acute myocardial infarction: association with genotype and adverse events. Arterioscler Thromb Vasc Biol 2006, 26:2800-06.

10. Karatela RA, Sainani GS: Interrelationships of factor VII activity and plasma leptin with insulin resistance in coronary heart disease. Atherosclerosis 2010, 209:235-40.

11. Cooper JA, Miller GJ, Bauer KA, Morrissey JH, Meade TW, Howarth DJ, Barzegar S, Mitchell JP, Rosenberg RD: Comparison of novel hemostatic factors and conventional risk factors for prediction of coronary heart disease. Circulation 2000, 102:2816-22.

12. Eriksson-Berg M, Silveira A, Orth-Gomer K, hamsten A, Schenck-Gustafsson K: Coagulation factor VII in middle-aged women with and without coronary heart disease. Thromb Haemost 2001, 85:787-92.

13. Green $\mathrm{F}$, Kelleher $\mathrm{C}$, Wilkes $\mathrm{H}$, Temple A, Meade T, Humphries S: A common genetic polymorphism associated with lower coagulation factor VII levels in healthy individuals. Arterioscler Thromb 1991, 11:540-6.

14. Bernardi F, Arcieri P, Bertina RM, Chiarotti F, Corral J, Pinotti M, Prydz H, Samama M, Sandset PM, Strom R, García W, Mariani G: Contribution of factor VII genotype to activated FVII levels. Differences in genotype frequencies between Northern and southern European populations. Arterioscler Thromb Vasc Biol 1997, 17:2548-53.

15. Mtiraoui N, Aboud N, Bouraoui H, Haizem S, Gris JC, Busson M, Tamim H, Almawi WY, Mahjoub T: Reduction in coagulation factor VII plasma levels by $\mathrm{R} 353 \mathrm{Q}$ but not the $-323 \mathrm{P} 0 / 10$ promoter polymorphism in healthy Tunisians. Am J Hematol 2005, 79:11-6.

16. Kathiresan S, Yang Q, Larson MG, Camargo AL, Tofler GH, Hirschhorn JN Gabriel Sb, O'Conell CJ: Common genetic variation in five thrombosis genes and relations to plasma hemostatic protein level and cardiovascular disease risk. Thromb Vasc Biol 2006, 26:1405-12

17. Bernardi F, Marchetti G, Pinotti M, Arcieri P, Baroncini C, Papacchini M, Zepponi E, Ursicino N, Chiarotti F, Mariani G: Factor VII gene polymorphisms contribution about one third of the factor VII levels variation in plasma. Arterioscler Thromb Vasc Biol 1996, 16:72-6.

18. Girelli D, Russo C, Ferraresi P, Olivieri O, Pinotti M, Friso S, Manzato F, Mazzucco A, Bernardi F, Corrocher R: Polymorphisms in the factor VII gene and the risk of myocardial infarction in patients with coronary artery disease. N Engl I Med 2000, 343:774-80.

19. Lacoviello L. DiCastelnuovo A, de Knijff P. D'Orazio A, Amore C, Arboretti R, Kluft C, Benedetta Donati M: Polymorphism in the coagulation factor VII gene and the risk of myocardial infarction. N Engl J Med 1998, 338:79-85.

20. Shikomata K, Kondo T, Ohno M, Takeshita K, Inden Y, Lino S, Saito H, Hirai M: Effects of coagulation Factor VII polymorphisms on the coronary artery disease in Japanese: Factor VII polymorphism and coronary disease. Thromb Res 2002, 15:493-8.

21. Geng X, Jin GD, Fu GS, Ji MA, Shann J, Wang JA: Polymorphisms in the genes for coagulation factor II, $\mathrm{V}, \mathrm{VII}$ in patients undergoing coronary angiography. J Zheiiang Univ Sci 2003, 4:369-73.

22. Ogawa M, Abe S, Biro S, Saigo M, Kihara T, Setoyama S, Matsuoka T, Toda H, Torii H, Atsuchi Y, Toyama Y, Tateishi S, Minagoe S, Maruyama I, Tei C: R353Q polymorphism, activated factor VII, and risk of premature myocardial infarction in Japanese men. Circ J 2004, 68:520-25.

23. Jeffery S, Poliniecki J, Leatham E, Bevan D, Ireson N, Talbot S, Cole D, Kaski JC: A protective contribution of the $\mathrm{Q}$ allele of the $\mathrm{R} 353 \mathrm{Q}$ polymorphism of the factor VII gene in individuals with cronic stable angina? Int J Cardiol 2005, 28:395-9.

24. Fujimaki T, Kato K, Yoshida T, Oguri M, Watanabe S, Metoki N, Yoshida H, Satoh K, Aoyagi Y, Nishigaki Y, Tanaka M, Nozawa Y, Kimura G, Yamada Y: Association of genetic variants with myocardial infarction in Japanese individuals with chronic kidney disease. Thromb Haemost 2009, 101:963-68.

25. Lane A, Green F, Scarabin PY, Nicaud V, Bara L, Humphries S, Evans A, Luc G, Cambou JP, Arveiler D, Cambien F: Factor VII Arg/Gln (353) polymorphism determines factor VII coagulant activity in patients with myocardial infarction (MI) and control subjects in Belfast and in France but is not a Strong indicator of MI risk in the ECTIM study. Atherosclerosis 1996, 119:119-27.

26. Batalla A, Alvarez R, Reguero JR, Gonzalez P, Alvarez V, Cubero GL, Cortina A, Coto E: Lack of association between polymorphisms of the coagulation factor VII and myocardial infarction in middle-aged Spanish men. Int J Cardiol 2001, 80:209-12.

27. Zheng Y, Liu E, Higgins J, Keavney BD, Lowe GD, Danesh : Seven haemostatic polymorphisms in coronary disease: meta-analysis of 66155 cases and 91397 controls. Lancet 2006, 367:651-58.

28. Maguire JM, Thakkinstian A, Sturm J, Levi C, Lincz L, Parsons M, Whyte S, Attia J: Polymorphisms in platelet glycoprotein $1 \mathrm{ba}$ and factor VII and risk of ischemic stroke: a meta-analysis. Stroke 2008, 39:1710-16.

29. WHO: Human Genetics Program. Familial hypercholesterolaemia, a global prospective. Ginebra: WHO; 1999.

30. Simera I, Mother D, Hirst A, Hoey K, Schultz KF, Altman DG: Transparent and accurate reporting increases reliability and impact of your research: reporting guidelines and the EQUATOR Network. BMC Med 2010, 26:8-24.

31. Simera I, Mother D, Hoey J, Schulz KF, Altman DG: A catalogue of reporting guidelines for health research. Eur J Clin Invest 2010, 40:35-53, Review.

32. World Health Organization Cardiovascular Diseases Unit: WHO MONICA Project: MONICA Manual. Geneva: World Health Organization; 1990

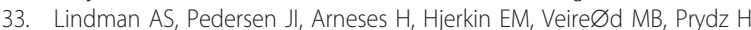
Seljeflot I: Coagulation factor VII, R353Q polymorphism, and serum choline-containing phospholipids in males at high risk for coronary heart disease. Thromb Res 2004, 113:57-65.

34. Baena Díez JM, del Val García JL, Tomás Pelegrina J, Martínez Martínez JL, Martín Peñacoba R, González Tejón I, Raidó Quintana EM, Pomares Sajkiewicz M, Altés Boronat A, Alvarez Pérez B, Piñol Forcadell P, Rovira España M, Oller Colom M: Cardiovascular disease epidemiology and risk factors in primary care. Rev Esp Cardiol 2005, 58:367-373.

35. Alonso R, Mata N, Castillo S, Fuentes F, Saenz P, Muñiz O, Galiana J, Figueras R, Diaz JL, Gomez-Enterría P, Mauri M, Piedecausa M, Irigoyen L, Aguado R, Mata P, Spanish Familial Hypercholesterolaemia Group: Cardiovascular disease in familial hypercholesterolaemia: influence of low-density lipoprotein receptor mutation type and classic risk factors. Atherosclerosis 2008, 200:315-21.

36. López-Miranda J, Badimon L, Bonanome A: Monounsatured fat and cardiovascular risk. Nutr Rev 2006, 64:S2-S12.

37. Gómez P, Fernández de la Puebla RA, Castro P, López-Miranda J, Marín C, Fuentes F, Pérez-Martínez P, Velasco F, Moreno JA, Torres A, PérezJiménez F: Effect of the Mediterranean diet on casting concentrations of activated factor VII in healthy persons. Rev Esp Cardiol 2005, 58:285-9.

38. de Sauge Noltin PR, Defesche JC, Buirma RJ, Hutten BA, Lansberg PJ, Kastelein JJ: Prevalence and significance of cardiovascular risk in a large cohort of patients with familial hypercholesterolaemia. J Intern Med 2003, 253:161-8.

39. Umans-Eckenhausen MA, Sijbrands EJ, Kastelein JJ, Defesche JC: Lowdensity lipoprotein receptor gene mutations and cardiovascular risk in a large genetic cascade screening population. Circulation 2002, 106:3031-6.

40. Civeira F, Castillo S, Alonso R, Meriño-lbarra E, Cenarro A, Artied M, MartínFuentes P, Ros E, Pocoví M, Mata P, Spanish Familial Hypercholesterolemia Group: Tendon xanthomas in familial hypercholesterolemia are associated with cardiovascular risk independently of the low-density lipoprotein receptor gene mutation. Arterioscler Thromb Vasc Biol 2005, 25:1960-5

41. van Aalst-Cohen ES, Jansen EC, Tanck MW, Defesche JC, Trip MD, Lansberg PJ, Stalenhoef AF, Kastelein JJ: Diagnosing familial hypercholesterolaemia: the relevance of genetic testing. Eur Heart J 2006, 27:2240-6.

42. Oosterver DM, Vermissen J, Yazdanpanah M, Defesche JC, Kastelein JJ, Sijbrands EJ: The risk of tendon xanthomas in familial hypercholesterolemia by variation in genes of the reverse cholesterol transport pathway and the low-density lipoprotein pathway. Eur Heart $J$ 2010, 31:1007-12.

43. Humphries SE, Whittall RA, Hubbart CS, Maplebeck S, Cooper JA, Soutar AK, Naoumova R, Thompson GR, Seed M, Durrington PN, Miller JP, Betteridge DJ, Neil HA, Simon Broome Familial Hyperlipidaemia Register Group and Scientific Steering Committee: Genetic causes of familial hypercholesterolaemia in patients in the UK: relation to plasma lipid levels and coronary heart disease risk. J Med Genet 2006, 43:943-9. 
44. Feng DL, Tofler GH, Larson MG, O'Donnell CJ, Lipinska I, Schmitz C, Sutherland PA, Johnstone MT, Muller JE, D'Agostino RB, Levy D,

Lindpaintner Ket: Factor VII polymorphism, factor VII levels, and prevalent cardiovascular disease-the Framingham heart study. Arterioscler Thromb Vasc Biol 2000, 20:593-600.

45. Lee AJ, Fowkes FGR, Lowe GDO, Connor Jm, Rumely A: Fibrinogen, factor $\mathrm{VII}$ and PAl-1 genotypes and the risk at coronary and peripheral atherosclerosis: Edinburgh artery study. Thromb Haemost 1999, 81:553-60.

46. Van der Krabben MD, Rosendaal FR, Van der Bom JG, Doggen CJ: Polymorphisms in coagulation factors and the risk of recurrent cardiovascular events in men after a first myocardial infarction. J Thromb Haemost 2008, 6:720-5.

47. Wu AHB, Tsongalis GJ: Correlation of polymorphisms to coagulation and biochemical risk factors for cardiovascular diseases. Am J Cardiol 2001 87:1361-6.

48. Rubattu S, Di Angelantonio E, Nitsch D, Gigante B, Zanda B, Stanzione R, Evangelista A, Pirisi A, Rosati G, Volpe M: Polymorphisms in prothrombotic genes and their impact on ischemic stroke in a Sardinian population. Thromb Haemost 2005, 93:1095-100.

49. Jansen AC, van Aalst-Cohen ES, Tanck MW, Cheng S, Fontecha MR, Li J, Defesche JC, Kastelein JJ: Genetic determinants of cardiovascular risk in familial hypercholesterolemia. Arterioscler Thromb Vasc Biol 2005, 25:1475-81.

doi:10.1186/1476-511X-10-50

Cite this article as: Criado-García et al:: R353Q polymorphism in the factor VII gene and cardiovascular risk in Heterozygous Familial Hypercholesterolemia: a case-control study. Lipids in Health and Disease 2011 10:50.

\section{Submit your next manuscript to BioMed Central} and take full advantage of:

- Convenient online submission

- Thorough peer review

- No space constraints or color figure charges

- Immediate publication on acceptance

- Inclusion in PubMed, CAS, Scopus and Google Scholar

- Research which is freely available for redistribution

Submit your manuscript at www.biomedcentral.com/submit
C Biomed Central 